
Wine-applications-far-drifling-permits were approved-by- the Divisionds-Petrataum Branch as follows:

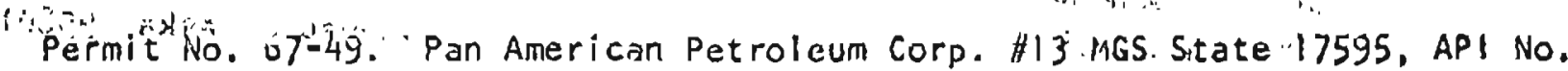
50-133-20039. Surface location: 1989' FWL and 588' FWL, Sec. 31, T9N, RI2W,

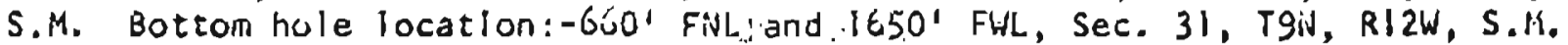
This development w'll is in the Middle Ground Shoal Field.

Permit Ho: 07-50. Pan American Petroieum Corp. Hl Redoubt Shoal State 29690,

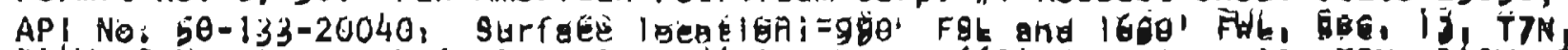
Rl4W, B.M. Bottom hole location:-660'. FNL and 660' FWL, Sec, 19, T7M, hl 3W. S.M. This exploratory locatlon is five miles sculliwest of Pan American's Dillion platform in the southern part of the hidd? Ground Shoal fleld.

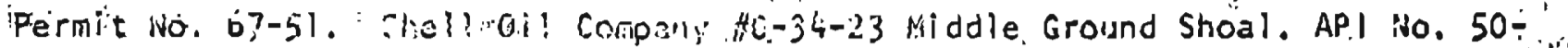

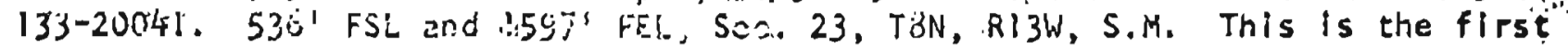
development well from Sheill's "C" pintform in the hilddle Ground Shoal Fleld.

Permit INo. 07-52. Pan American Petroleum Corp. \#6 South Middle Ground Shoal Unit, API No. 50-13.3-20042.. og9' FSL and 1872' FW, Sec. 35, TON, Rl3W, S.M. This development well Is in tho isouchera, part of the Middle Ground shoal field ${ }_{i}$ :

Permit Ho. 67-53. Union 0il Company of California \#A-8 Trading Bay state, API No. 50-133-20043. Surface location:-1012' FSL and 577' FEL, Sec. 4, T9H, RI3W;' S.M. Bottem hole location:-2100' FSL and 2.155! Fl.J, Sec. 4, T9M, Ri3W, S.M. This is a davelopment location in tha Trading Bay Fleld.

Permit No..67-54.: Pan: Amcrican Pctroleum Corp. H4 Granite Point State 17536. API No: 50-253-20009. Surface iocation:- 2009! FSL and 1943'. Fil , Sec. 31. TIIN. RI.IW, s.im. Bottam hols location:- 1980! FNL and 660' FEL, Sec. 36, TïiN; Rl2W, S.M: This is: a location for a develapment well in the Granite Polnt Fiely:

Permit: No. 67-55. Shell Oi.l Company HA-12-12 Middle Ground Field API No. 50-13320044: Surface locetion:-..j503' FSL and 378. FEL, Sec. 11, TÜN, R13W, S.M. - Brittóm trole location:-2100'. FiNL arid 970' FWL, Sec. 12, T8N. RI3W, S.M. This is

is location for a development well in the Middle Ground Shoal field.

Petmi : Vo. 67-56. Union Oil Company of California Hl Kasilaf Unit, API No." 50-133-20045: 1980. FHL and 2310' FEL, Sec. 30, T3N, Ri2W, This offshore ex-

- "p'lorstory locatigr is aúlit ten miles southwest of the Kenai gas field.

Permit No.1:67-57. Mobi? 011 Corporation \#11-24 Granite Point State, API No. 50-133-20046: Surface location: 23i3' FNL and 1363! FWL, Sec. 13, TIOK,'RI2W,

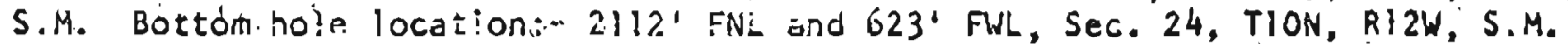
This is a platform.deveiopment iocation at the south end of the Grarite point Field.

\section{Erilling: Activity}

\section{Operator}

Atlantic Richficid Co. Atlantic nichfield Co.

\section{Well Names \& Numbers}

Midrie River State Unit Prudhos Bay fil

\section{Type 'status: \\ E Drilling \\ E Temp. Susp.}


Operator

Atlantic Richfield Co.

Humble Oil E Refining Co.

Marathon Oil Company

Mobil oil Corp.

Mobil Uil Corp.

Mobil oil Corp.

Mabil. Oil Corp.

Plobil 0il Corp.

Pan Amerlcan Petroleum Corp.

Pari Amatican Petroloum Corp.

Pan Amerícan Petroleum Córp.

Pan Anerican Petroleum Corp.

Pan American Petroleum Corp.

Pan American Petroleum Corp.

Pan American Petroleum Corp.

Pan American Petroleun Corp.

Pan Amerjican Petroleum Corp.

Pan Amer ican Petroleum Corp.

Pan American Petroleum Corp.

Pan American Petroleum. Corp.

Pan Anierican Petroleum Córp.

Pan Anierican Petroleuni Corp.

Pennzoll Company

Shell oil Company

Shell oil Company

Shell Dil Company

Shell oil Company

Shell oll Company

Standard Oil Co. of Calif.

Superior Oil Company

Tenneco oil. Company

Union Oli Co. of Cali.f.

Union 011 Co. of Calif.

Union Oi. . Co. of Calif...

Union Oll Co. of Calif.

Union Oil Co. of Calif.

Union Oil Co. of Calif.
Well Names \& lumbers

Trading bay State $\# 2$

Tyonek Reserve "B" \#1

Beaver Creek $\$ 2$

Granite Point State $11-13$

Granite Point State $\$ 11-24$

Granite Point State \#13-13

Granite Point State $\# 31-14$

Tower H2

Albert Kaloa \#l

Granite Point State $17506 / 14$

Granite Point State 18742 \$5

Granite Point State 18742 \#7

Granithe Point State $18742 \$ 8$

Granite Point State 18742 \$9

Granite Point State $18742 \# 10$

MGS State 17545 \#10

MGS State 17595 \#11

MGS State 17595 H13

Redoubt Shoal State 29690 \#

South PiGS Unit \#2

South MGS Unit \#3

South MGS Unit

Starichkof Unit \#1

Kustatan Ridge 1

A-12-12

MGS \#A-42-14

MGS $\# A-44-11$

MGS \#C-34-23

Beluga River Unit \#14-3

Three Mile Creek State 1 i....

State 36465 \#

Kasilof Unit

Kenai Deep Unit

Trading Bay Stafe HA-7

Trading Bay State \#A- $\delta$

State $6-1 \quad(32-28)$.

State $G-2(34-29)$
Type Status

Abandoned

Drilling

Orilling

Completing

Location

Orilling

Comp. oil well

Drilling

Drilling

Drilling

Comp ofl well

Testing.

Pród oi weit

Drilling

Drilling

Completting ir.

Testing

Drilling

Drilling

Testing

Drilling

Drilling

Abandoned

Abandoned

Location

Drilling

Comp. oll well

Dellling

Abandoned

Drilling

Drilling

Location

Drilling

Drilling

Location

Drilling

Drilling

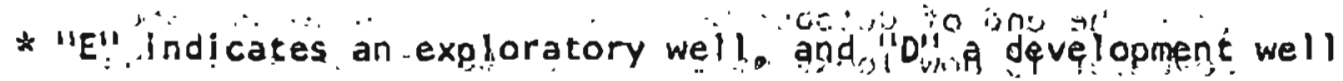

$\because \mathrm{rioi}$

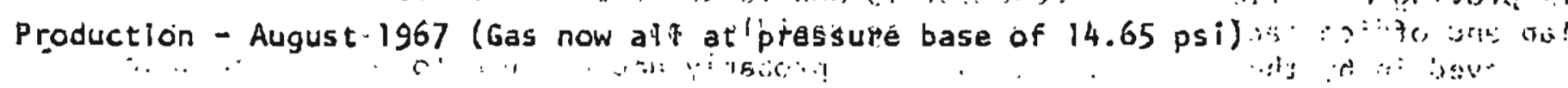

Field

Swanson River fleld

\section{3! Zone}

Hemilock

Prod: Hells

, in in 138

:

Injection
Hemlock

Middle Ground Shoal: Hemlock: , . 20

$$
\because \quad \therefore \quad \therefore(\text { Incl } 4 \text { duals }
$$

0il, Bbls.. $\frac{\text { Gas, MEF }}{\text {. }}$

$\$, 034,760: \quad 1,093,471$

$70,374,092 *$

$26,376,967 \star$

$3.991,258$

$70,290,099 *$

534,751
$6,622,795 *(1)$

245,323

$2.953,036 *$ 


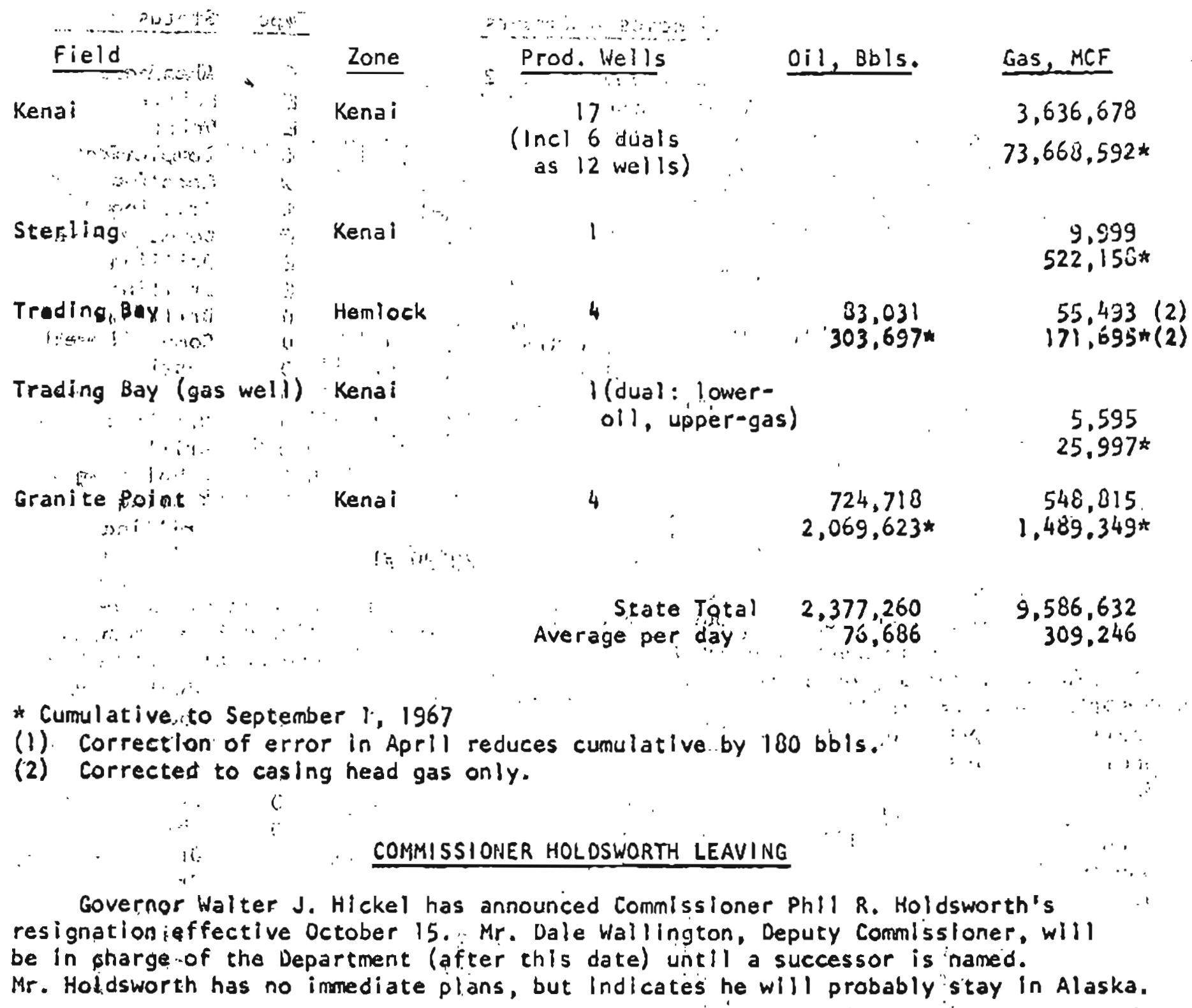

\section{DIVISION HOVE NEWS}

Our last month's guess that the end of October would see us moved to College. is proving a little early. November 15 now looks quite firm. Constructlon on the rab and office facllities is proceeding rapidly, and it. Is, estimated that we can, be moved in by the latter date. We will probably not be able to get out another Bulietin before the move. The Division's address after the move will be College, Alaska, 99701. As a personal note, friends will be interested to know that the ipirector's wife is practically moved up there now.

\section{STATE PARK REGULATIONS PROPOSED}

Verbal information has just been received from the State Oivision of Lands that proposed State Park Regulations will soon be subject to public hearings around the State. Mining people should acquaint themselves withithese proposals and be:. ready to testifycat the hearings ilfuithey have suggestions or objections. Watch for announcements from the Division of lands or concact them at $344 \mathrm{Sixth}$ Avenue, Anchorage for schedules of hearings and advance copies of the proposed regulations. 


\section{MINIING EXTENSIOW COURSE SCHEDULE}

The 1967-63 sehedule of University of Alaska Mining. Extension courses is shown below.. These courses are tuition-free and are taught to 5 timulate interest in : rospecting. Majon emphas is oin the general prospecting course is an rapid identification of the important ore minerals. The geochemical course does not require any previous knowledge of chemistry. For further information, write to:

. : Summer Sessions, Conferences $\varepsilon$ Short Courses:

\section{Univarsity of Alsoka}

colloga, Alaska 99701

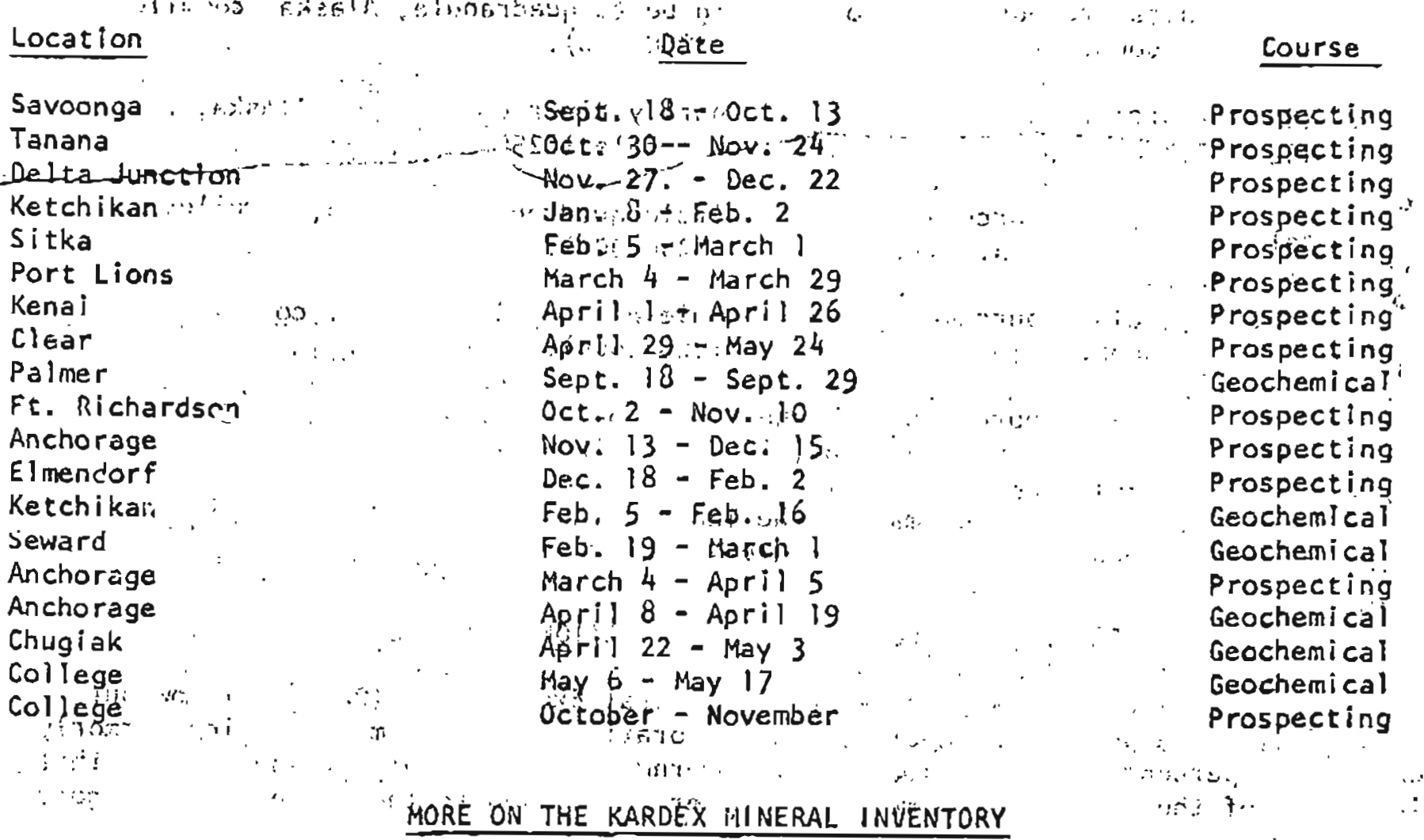

Following the publication of our rather lengthy article describling the featurts and workings of our Kardex file of mineral deposits and mining claims of the State last morith', we received: al letter from Arthur $E$. Gloyer 'reminding us of something we liad forgotten. Art'wa's Assayer for the old Territoria' Department of Mines from about 1937 to about 1955. Héstarted" compliting a card fite of mineral occurrences about 1943 and worked on it until" the present Kardex system was set up in 1953. He mentions that George Gates and Edwärid Cob'b of the Alaskan Geology Branch of the USGS used to drop th and make use of this" fille occasionally. Art's file may' have been the in : .:: spiration for the USGS card file on which our Kardex file was based, for it was : : : 4 Ed Cobb who was the chief architect of that very useful item. Ir:identally, we also forgot tó mention last month that the USGS minegal piccurrence card file was later. printed as USGS Bulletin $1139^{\circ}$ lindex of metall, iciand nongetallic mineral deposlts of Alaska compiled from published repores of Federal and State Agencies through 1959 by E.H. Cobb and R. Kachadoopjahi. This. bulletin can be purchased from the Superintendant of Documents (not the Divjstion of Mines and Minerals), Washington, D.C., 20402: for \$1.50. It is a valuable reference tem for locating published information on prospects and determining what prospects miay be in certain areas. Ed cobb is still turning out Lseful mineral information item' as' will be noted under the following articles, INEW PUBLICATIONS. 
The U.S. Geological Survey has released on open file the reports listed below. These: reports, can be seen in the various USGS and DMEM offices in Alaska.. Copies, will be made at private expense at the, Alaskan;Branch, U.S. Geological. Survey, 345. Middlefield Poad, Menlo Park, Galifornia, $94025 \ldots$ Please do not order these reports from the Dlvision of Mines and Minerals.,...,

Subsurface stratigraphic, 5 tructural and economic geology, northern Alaska, by Florence R. Collins and Florence M. Robinson. 259:P., $19 \mathrm{pl}$, , $16 \mathrm{figs}$.

2 tables.

Hetallic mineral resources map of the big Delta quadrangle, Alaska, compiled by Edward H. Cobb. 4 p., 1 map (scale 1:250,000).

Thetall lo mineral resources map of the Charley River quadrangle, Alaska, compli.ed:by Edward H. Cobb. 3 p., : I map (scale 1:250,000). $\because \div$

Hetallicimineral resources map of the circle quadrangle, Alaska, complled: by: Edward K. Cobb. $6 \mathrm{N.}, 1$ map (scale $1: 250,000)$ :

Metalific mineral resources map of the Eagle quadrangle, Alaska, complled by Edward"H. Cobb. 8 p., 1 map (scale: 1:250,000).

Metallic mineral resources map of the Livengood quadrangle, Alaska, compiled by Edward H. Cobb. II p.! I srap-(scale $1: 250,000)$.

Metallic mineral resources map of the. Tanana:quadrangle, Alaska, complled by: Edward H. Cobb. \& p., 1 map (scale:1:250;000).

\section{FEDERAL AID FOR MIMERAL T'EẌPLO'RATION INCREASED}

The U.S. Geological Survey's Office of Mineral Exploration (OME) 'will now put up a maximum of 75 percent of the cost of exploration for eight metais which formerly drew only 50 percent partlcipation by the government. It is interesting to note that gold is one of the newly-raised metals.. sliver was raised to the 75-percent category sometime ago.

To âjaly For a joan, an applicant musthave a valid ihterest in the property to be explored the expectable ores must be valuable principalty for minerals that are on the supportilisti good posibilities for making a significant discovery must exists and the property must be accessible. Also, it inut be shown that the applicant could not do the work at his own expense, and that furids for exploration are not availiable to him on reasonable terims from comercial sources. "The applicant must also show that he has funds to meet his share of the costs arid to spport the operation until governmentel relmbursement is óbtained.

3. The following minerals and mineral products are eligible for astistance under the oME program with the maximum amount of government participation as indicated:
Yi
Ant imony. 75\%'.
Asbestos 50\%
Bauxite $50 \%$
soi zrowist
Berylilium $506^{\circ}$
Bismu th $75 \%$
Cadmitum $50 \%$

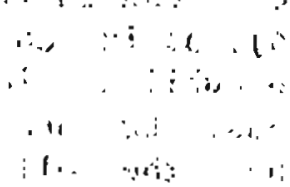
if.
chrom té $50 \%$
Cóbalt $50 \%$

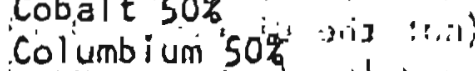
Cópper 50\%
'Cortundum' $50 \%$ '.
o'lamond (industrial) $50 \%$ 


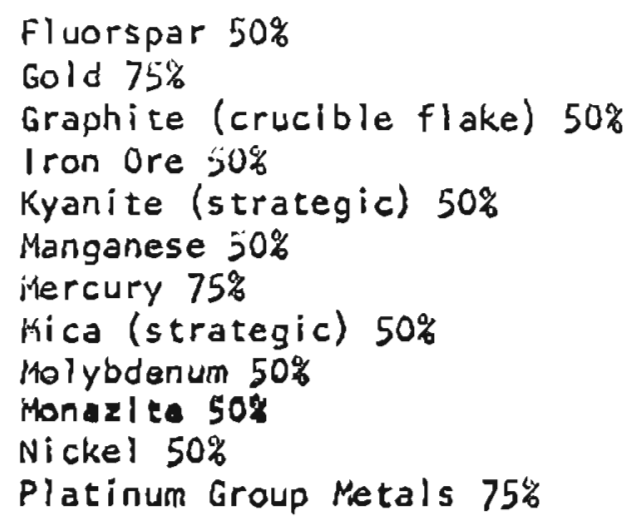

Administration of the OME program in Alaska is headquartered at the following address: Field office, Region 11 , OPAE, Geological Survey Building 2, 345 Middlefield Road, Menlo Park, Callfornia 94025. Applications and further information may be obtained from that office.

E. AND M.J. METAL HARKET PRICES

\begin{tabular}{|c|c|c|c|}
\hline & $\begin{array}{c}\text { September } 25 \\
1967 \\
\end{array}$ & Month Ago & Year Ago \\
\hline $\begin{array}{l}\text { Copper, per lb. } \\
\text { Lead, per ib. } \\
\text { Zinc, per ib. } \\
\text { Tin, per lb. } \\
\text { Nickel, per ib. } \\
\text { Platinum, per oz. } \\
\text { Mercury, per flask } \\
\text { Antimony ore, per unit } \\
\text { Beryllium powder, } 98 \mathrm{f} \text { per ib. } \\
\text { Chrome ore, per iong ton } \\
\text { Molybdenum Conc., per lb. } \\
\text { Titanium ore, per ton } \\
\text { Tungsten, per unit } \\
\text { Silver, New York, per oz. } \\
\text { - }\end{array}$ & $\begin{array}{l}\text { Suspendedt } \\
14 c \\
14 c \\
151.1 c \\
05.25 c-94 c \\
\$ 109-112 \\
\$ 495-512 \\
\$ 5.20-6.20 \\
\$ 54-60 \\
\$ 31-35 \\
\$ 1.62 \\
\$ 21-24 \\
\$ 43.00 \\
169.986\end{array}$ & $\begin{array}{l}39.1 c \\
14 c \\
14 c \\
151.96 \\
65.25 c \\
\$ 109-112 \\
\$ 490-495 \\
\$ 5.20-6.20 \\
\$ 54-66 \\
\$ 31-35 \\
\$ 1.62 \\
\$ 21-24 \\
\$ 43.00 \\
169.506\end{array}$ & $\begin{array}{l}31.16 \\
15 c \\
1.5 c \\
154.65 c \\
77.756 \\
\$ 100 \\
\$ 470-490 \\
\$ 4.55-5.55 \\
\$ 54-66 \\
\$ 31-35 \\
\$ 1.55 \\
\$ 21-24 \\
\$ 43.00 \\
129.36\end{array}$ \\
\hline \multicolumn{4}{|c|}{$\begin{array}{l}\text { E. E M.J. Metals Week says the following: "With virtually all domestic copper } \\
\text { production struck and with the pipelines now about empty, Hetals Week feels that there } \\
\text { is not a sufficient tonnage of producer copper being sold in the U.S. to calculate a } \\
\text { meaningful weighted average. Foreign-produced-and higher-priced-copper would take on } \\
\text { too great a weighting in the calculation, and consumers would be hit with an expected } \\
\text { and unfair increase in their copper cost5. Consequently, the E. E M. J. domestic } \\
\text { average will be suspended until a representative tonnage of U.S.-produced copper is } \\
\text { again belng sold." }\end{array}$} \\
\hline
\end{tabular}

